\title{
Glucagon-like Peptide-1 Can Reverse the Age-related Decline in Glucose Tolerance in Rats
}

\author{
Yihong Wang, Riccardo Perfetti, Nigel H. Greig, Harold W. Holloway, Kimberly A. DeOre, Chahrzad Montrose-Rafizadeh, \\ Dariush Elahi, and Josephine M. Egan \\ Diabetes Section, Laboratory of Clinical Physiology, Gerontology Research Center, National Institute on Aging, National Institutes of \\ Health, Baltimore, Maryland 21224
}

\begin{abstract}
Wistar rats develop glucose intolerance and have a diminished insulin response to glucose with age. The aim of this study was to investigate if these changes were reversible with glucagon-like peptide-1 (GLP-1), a peptide that we have previously shown could increase insulin mRNA and total insulin content in insulinoma cells. We infused $1.5 \mathrm{pmol} /$ $\mathrm{kg}^{-1} \cdot \mathrm{min}^{-1}$ GLP-1 subcutaneously using ALZET microosmotic pumps into 22-mo-old Wistar rats for $48 \mathrm{~h}$. Rat infused with either GLP-1 or saline were then subjected to an intraperitoneal glucose ( $1 \mathrm{~g} / \mathrm{kg}$ body weight) tolerance test, $2 \mathrm{~h}$ after removing the pump. 15 min after the intraperitoneal glucose, GLP-1-treated animals had lower plasma glucose levels $(9.04 \pm 0.92 \mathrm{mmol} / \mathrm{liter}, P<0.01)$ than saline-treated animals (11.61 $\pm 0.23 \mathrm{mmol} / \mathrm{liter})$. At $30 \mathrm{~min}$ the plasma glucose was still lower in the GLP-1-treated animals $(8.61 \pm 0.39$ $\mathrm{mmol} /$ liter, $P<\mathbf{0 . 0 5})$ than saline-treated animals $(\mathbf{1 0 . 3 6} \pm \mathbf{0 . 4 3}$ $\mathrm{mmol} / \mathrm{liter})$. This decrease in glucose levels was reflected in the higher insulin levels attained in the GLP-1-treated animals (936 $\pm 163 \mathrm{pmol} / \mathrm{liter}$ vs. $395 \pm 51 \mathrm{pmol} / \mathrm{liter}$, GLP-1 vs. saline, respectively, $P<0.01$ ), detected $15 \mathrm{~min}$ after glucose injection. GLP-1 treatment also increased pancreatic insulin, GLUT2, and glucokinase mRNA in the old rats. The effects of GLP-1 were abolished by simultaneous infusion of exendin [9-39], a specific antagonist of GLP-1. GLP-1 is therefore able to reverse some of the known defects that arise in the beta cell of the pancreas of Wistar rats, not only by increasing insulin secretion but also by inducing significant changes at the molecular level. (J. Clin. Invest. 1997. 99:2883-2889.) Key words: insulin • glucose • glucagon • beta cell • aging
\end{abstract}

\section{Introduction}

Gastrointestinal peptides modulate the secretion of digestive enzymes and hormones. The classic gastrointestinal peptides, gastrin, cholecystokinin, and secretin also stimulate insulin re-

Address correspondence to J.M. Egan, M.D., Diabetes Section Box 23, NIA/GRC, 4940 Eastern Ave., Baltimore, MD 21224. Phone: 410558-8198; FAX: 410-558-8381; E-mail: eganj@vax.grc.nia.nih.gov

Received for publication 22 October 1996 and accepted in revised form 31 March 1997.

1. Abbreviations used in this paper: Ex, exendin [9-39]; GIP, glucosedependent insulinotropic peptide; GLP-1, glucagon-like peptide-1; IPGTT, intraperitoneal glucose tolerance test.

The Journal of Clinical Investigation

Volume 99, Number 12, June 1997, 2883-2889 lease. Glucose-dependent insulinotropic peptide (GIP) and glucagon-like peptide-1 (GLP-1), two hormones secreted from neuroendocrine cells of the gut, have the most potent insulinsecreting effect $(1,2)$. GLP-1 and GIP not only positively modulate acute glucose-mediated insulin release but have additional positive effects beyond simply increasing insulin secretion. They increase insulin biosynthesis and proinsulin gene expression when added to insulin-secreting cell lines for $24 \mathrm{~h}$ $(3,4)$ i.e., they are truly insulinotropic. They also induce an increase in hexokinase messenger RNA levels, GLP-1 being more potent than GIP $(5,6)$. GLP-1, unlike GIP, also is a potential agent in the treatment of Type II diabetes mellitus (7). It increases insulin release even in subjects with long-standing Type II diabetes (8). All in vivo studies have examined either bolus injections or short infusions of GLP-1 and to date the only parameter of GLP-1 action that has been looked at is its effect on insulin secretion. It remains to be determined whether or not longer infusions might have an impact on insulin biosynthesis, proinsulin gene expression, or on the glucose sensing mechanism of beta cells.

There is evidence to suggest that GLP-1 can cause downregulation of its own receptor when beta cells are treated acutely with GLP-1 $(9,10)$. However, we have shown that when RIN 1046-38 cells were treated with GLP-1 for $24 \mathrm{~h}$ there was an increase in GLP-1's insulinotropic effect (5), showing no evidence for the down-regulation of its biological effects. Thus, it appears that acute treatment does not reflect what would happen with more prolonged exposure to GLP-1.

Examination of prolonged effects of GLP-1 on beta cells in animals with normal glucose tolerance may not provide any evidence of enhanced insulinotropic effects of GLP-1 since, by definition, there is a state of normal glucose tolerance and the beta cells should be working at peak efficiency. By contrast, in animals with documented glucose intolerance, an up-regulation by GLP-1 might be induced. In aging Wistar rats, there is a decrease in glucose tolerance and insulin secretion, with altered first phase response being the most dramatic feature (11, 12). Parenthetically, first phase insulin release is also diminished or absent in Type II diabetes and is one of the first signs of impairment in glucose tolerance that may lead to Type II diabetes $(13,14)$. We have recently confirmed a decrease in glucose-mediated insulin release with age in Wistar rats and we have also shown that from 13 mo of age onward there is a progressive decline in insulin messenger RNA in islets of Langerhans and a decline in total pancreatic insulin content (15). As GLP-1 in cultured insulinoma cells is known to have a positive impact on insulin secretion, insulin synthesis, and insulin messenger RNA, we decided to look at GLP-1's effects on aging Wistar rats.

Therefore, the aims of this study were to investigate $(a)$ if the changes we had seen in an insulinoma cell line were applicable in an in vivo setting; $(b)$ if GLP-1 was capable of revers- 
ing the age-related decline in glucose tolerance; and $(c)$ investigate the possible molecular mechanisms for changes in beta cell activity that may be responsible for improving glucose tolerance. We used the Alzet micro-osmotic pump (Alza Corp., Palo Alto, CA) to infuse GLP-1 for $48 \mathrm{~h}$ continuously into aged Wistar rats. We show that GLP-1, when given subcutaneously, has marked beneficial effects on beta cell function in old animals and is capable of up-regulating expression of critical genes involved in insulin secretion and glucose sensing.

\section{Methods}

Materials. GLP-1 and exendin [9-39] (Ex), a peptide receptor antagonist of GLP-1, were purchased from Bachem (King of Prussia, PA). Chemical reagents were from Sigma (St Louis, MO), unless otherwise stated.

Animals. 3-mo (young) and 22-mo (old) old Wistar rats from the Wistar colony in the National Institute on Aging (NIA) (Baltimore, $\mathrm{MD})$ were used throughout. They had been maintained on rat chow and fed ad libitum. All our aged rats are the offspring of 10 founder families maintained at the NIA.

Protocols. To insure that old animals were capable of responding to GLP-1, we carried out an acute experiment with an intravenous bolus of GLP-1. Six old and six young rats were deprived of food overnight. After anesthesia with $50 \mathrm{mg} / \mathrm{kg}$ pentobarbital, a catheter was placed in the femoral artery for blood sampling, and a bolus of GLP-1 (0.1-0.4 nmol $/ \mathrm{kg})$ was given into the saphenous vein over $30 \mathrm{~s}$. Blood (taken at 2, 4, 7, and $10 \mathrm{~min}$ ) was collected for insulin determination.

The rats were implanted with an Alzet micro-osmotic pump (Alza Corp.) in the interscapular region for $48 \mathrm{~h}$. In the treated groups (young and old) GLP-1 was delivered at the rate of 1.5 and Ex (old group only) at $15 \mathrm{pmol} / \mathrm{kg}^{-1} \cdot \mathrm{min}^{-1}$. It has been shown that to prevent GLP-1's insulinotropic effect a 10-fold higher concentration of Ex is required (16). Control animals received normal saline in their pumps and received their infusion for the same length of time.

For glucose tolerance testing, after the pumps were in place $36 \mathrm{~h}$ ( $n=6$ each for control and GLP-1 treatment), the rats were fasted overnight, anesthetized with $50 \mathrm{mg} / \mathrm{kg}$ pentobarbital, and the pumps were removed, giving a total GLP-1 infusion time of $48 \mathrm{~h}$. A catheter was placed in the femoral artery for blood sampling and blood was collected for GLP-1 measurement. An intraperitoneal glucose tolerance test (IPGTT, $1 \mathrm{~g} / \mathrm{kg}$ body wt) was administered $120 \mathrm{~min}$ after removal of the pumps. Blood samples $(200 \mu \mathrm{l})$ were obtained at 15,30 , 45, 60, and $90 \mathrm{~min}$ to estimate glucose and insulin levels.

For intraislet content of insulin, 14 old rats were used. Seven were treated with GLP-1, and seven with saline, as described above. After $48 \mathrm{~h}$, preceded by an overnight fast, the animals were killed and islets of Langerhans were harvested as described previously $(15,17)$. We then measured the intraislet insulin content in 50 islets picked at random from each individual pancreas. Picked islets were centrifuged, any residual medium was removed, the pellet was suspended in icecold acid-ethanol $(500 \mu \mathrm{l})$ and homogenized. After centrifugation of the homogenate $\left(1,400 \mathrm{~g}, 4^{\circ} \mathrm{C}\right)$ the supernatant was collected for measurement of intracellular insulin. The pellet was dissolved in formic acid and protein content was determined.

Assays. Plasma glucose was measured by the glucose oxidase method (17). Insulin and GLP-1 were measured by RIA as previously published $(5,18)$. The amount of cellular proteins was measured using the Bradford method (Bio-Rad, Richmond, CA) using bovine $\gamma$-globulin as standard.

$R N A$ isolation and quantitation of pancreatic mRNAs. Whole pancreata of rats ( 6 animals per group) that had been subjected to $48 \mathrm{~h}$ infusion with GLP-1, Ex \pm GLP-1, or saline were used to extract total RNA. After an overnight fast, animals were killed, pancreata were removed and frozen in liquid nitrogen as quickly as possible. RNA was extracted by homogenization in guanidinium isothiocyanate, fol- lowed by ultracentrifugation on a $5.7 \mathrm{M}$ cesium chloride cushion (19, 20). Poly-A RNA was then prepared from total RNA by affinity chromatography using oligo (dT) columns (Bio Labs Inc., Beverly, MA). RNA was quantified by spectrophotometric analysis at 260-nm wavelength. Slot blot analysis using poly-A RNA was used for quantitation of mRNA levels of glucokinase, which is the main glucose sensor of the beta cell (21), the three hexokinases, GLUT2, the major glucose transporter of the beta cell (22), and insulin. $4 \mu \mathrm{g}$ poly-A RNA were diluted in $50 \mu \mathrm{l}$ TE buffer (Tris- $\mathrm{HCl} 10 \mathrm{mM}$, EDTA 1 $\mathrm{mM}, \mathrm{pH} 7.4), 20 \mu \mathrm{l}$ of $37 \%$ formaldehyde and $20 \mu \mathrm{l}$ of $10 \times$ SSC. Samples were incubated at $60^{\circ} \mathrm{C}$ for $15 \mathrm{~min}$ and then diluted with 1 $\mathrm{ml}$ of ice-cold $10 \times \mathrm{SSC}(1 \times \mathrm{SCC}=0.15 \mathrm{M} \mathrm{NaCl}+0.015 \mathrm{M}$ sodium citrate). Each well of slot blot minifolder was rinsed once with icecold $10 \times$ SSC and $300 \mu \mathrm{l}$ of sample per well was then loaded in triplicate onto the membrane. Vacuum was applied to drain the samples through the membrane, followed by three washes of the wells with ice-cold $10 \times$ SSC. Finally, membranes were baked for $2 \mathrm{~h}$ at $80^{\circ} \mathrm{C}$ in a vacuum oven.

The hybridizations with cDNA probes (rat insulin II from Dr. S.J. Giddings, Washington University, St. Louis, MO; rat glucokinase from Dr. M.A. Magnuson, Vanderbilt University, Nashville, TN; rat GLUT2 from Dr. M.J. Birnbaum, Harvard Medical School, Boston, MA; and hexokinase I, II, III cDNAs from Dr. J. E. Wilson, Michigan State University, East Lansing, MI) were carried out as previously described $(5,6)$. All cDNA probes were labeled with $\left[{ }^{32} \mathrm{P}\right] \mathrm{dCTP}(\mathrm{Am}-$ ersham Life Science, Arlington Heights, IL) by random priming procedure using Sequenase (United States Biochemical, Cleveland, $\mathrm{OH}$ ). An oligonucleotide named oligo $\mathrm{dT}_{20}$ homologous to the poly-A tail of mRNAs was synthesized on an Applied Biosystem DNA synthesizer (5'GATGGATCCTGCAGAAGCTTTTTTTTTTTTTTTTTTTT3') and used to quantify total cellular mRNA. Hybridization with oligo $\mathrm{dT}_{20}$ was carried out in order to verify that an approximately equal amount of RNA was used for each sample. Oligonucleotide probes were end-labeled with $\left[{ }^{32} \mathrm{P}\right] \gamma$ ATP (Amersham) using T4 polynucleotide kinase (New England Biolabs, Beverly, MA). The hybridizations with oligonucleotide probes were carried out as described before $(5,6)$ and quantified using a Betascope 603 blot analyzer (Betagen, Waltham, MA).

$R N A$ isolation and quantitation of mRNAs in islets of Langerhans. Total RNA was prepared from isolated islets of Langerhans from old animals treated for $48 \mathrm{~h}$ with GLP-1 or saline using the micromethod previously described by us (15). Approximately $5 \mu \mathrm{g}$ of total islet RNA was extracted per pancreas. Slot blot analysis was applied for quantitation of mRNA levels of glucokinase, the hexokinases, GLUT2, and insulin, as described above.

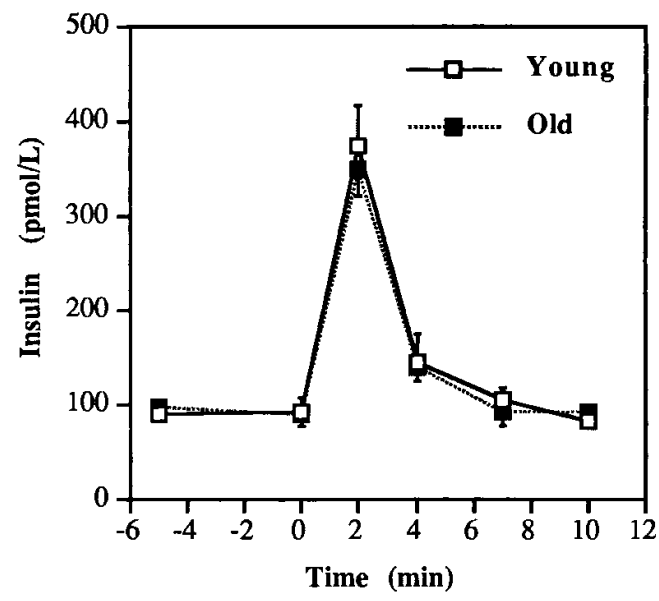

Figure 1. Plasma insulin levels in 3-mo and 22-mo old animals. GLP-1 $(0.2 \mathrm{nmol} / \mathrm{kg}$ i.v. $)$ was given to fasted, anesthetized animals. The results are shown as mean \pm SEM of 6 animals in each age group. 

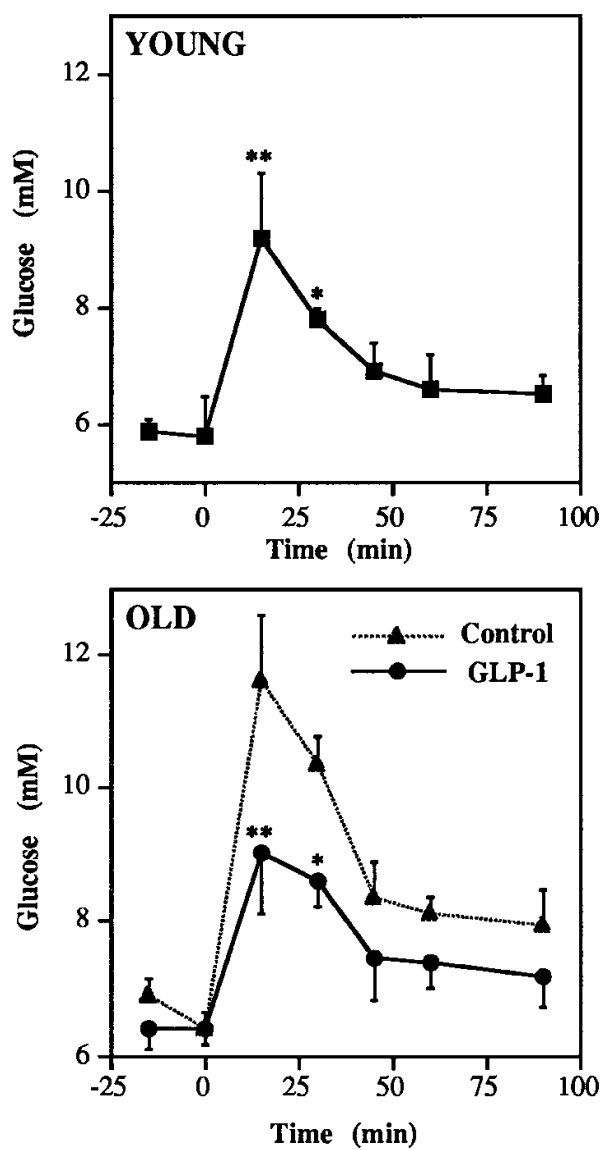

Figure 2. Plasma glucose levels during an IPGTT $(1 \mathrm{~g} / \mathrm{kg})$ in young (3 $\mathrm{mo})$ and old (22 mo) rats. GLP-1-treated old animals received 1.5 $\mathrm{pmol} / \mathrm{kg} \cdot \mathrm{min}$ for $48 \mathrm{~h}$ by subcutaneous infusion. All other animals were infused for $48 \mathrm{~h}$ with saline. The results are shown as mean \pm SEM of 6 animals in each group. Repeated measures analysis of variance from 0 to $30 \mathrm{~min}$ showed a value of $P<0.05$ for the GLP-1-treated vs. control old animals. $* P<0.05$, $* * P<0.01$, as determined by unpaired Student's $t$ test for control young vs. control old animals and for GLP-1-treated vs. control old animals.

Statistical analysis. The data were expressed as the mean \pm SEM. Significance of the insulin and glucose data obtained from the IPGTT was tested using repeated measures analysis of variance by SAS (SAS Institute Inc., Cary, NC). If a significant interaction was documented $(P<0.05)$, values at single time points were compared by nonpaired Student's $t$ test. All other data were analyzed using the nonpaired Student's $t$ test: a $P<0.05$ was judged as significant.

\section{Results}

Response to acute intravenous GLP-1 bolus. Old and young fasted animals responded equally well to a bolus of $0.2 \mathrm{nmol} / \mathrm{kg}$ GLP-1 delivered over 30 s i.v. Their insulin responses were superimposable (Fig. 1). At 2 min after completion of the bolus the insulin response was maximal in both young $(373.3 \pm 43.7$ pmol/liter) and old (347.7 $\pm 25.7 \mathrm{pmol} / \mathrm{liter})$ animals and in both groups insulin levels had returned to baseline at $10 \mathrm{~min}$. Maximum insulin response to GLP- 1 was at $0.4 \mathrm{nmol} / \mathrm{kg}$ in both young and old and there also was no statistical significance in the time of release or the amount released.

Glucose tolerance testing. Old animals have frank glucose intolerance when compared to young animals during an IPGTT

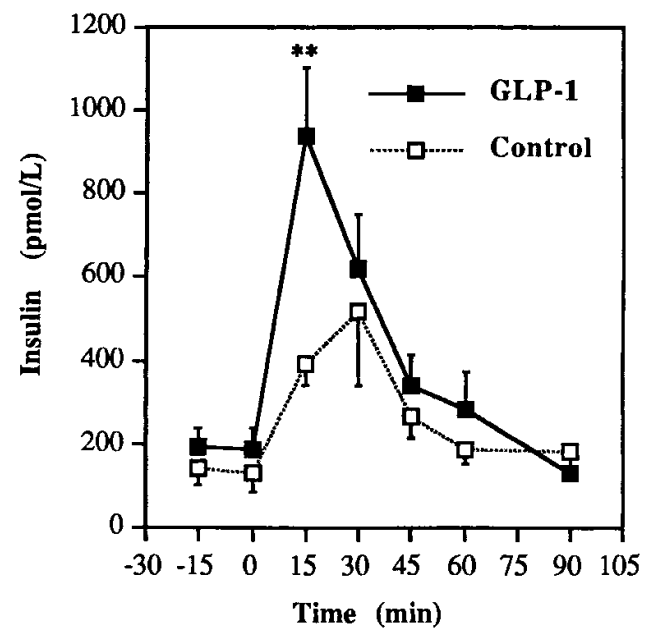

Figure 3. Plasma insulin levels during an intraperitoneal glucose $(1 \mathrm{~g} / \mathrm{kg})$ tolerance test in 22-mo old animals. GLP-1-treated animals received $1.5 \mathrm{pmol} / \mathrm{kg} \cdot \mathrm{min}$ for $48 \mathrm{~h}$ by subcutaneous infusion. Controls were infused with saline. The results are mean \pm SEM of 6 treated and 6 control animals. Repeated measures analysis of variance from 0 to $30 \mathrm{~min}$ showed a value of $P<0.05 . * P<0.01$, as determined by unpaired Student's $t$ test.

(Fig. 2). Fasting glucose, taken just before the intraperitoneal glucose, was not different between treated and control animals. Blood glucose was significantly lower during the glucose tolerance test in the animals treated with GLP-1 when compared with control old animals at the $15-(9.04 \pm 0.92$ vs $11.61 \pm 0.23 \mathrm{mmol} / \mathrm{liter})$ and $30-(8.61 \pm 0.39 \mathrm{vs} 10.36 \pm 0.43 \mathrm{mmol} /$ liter) min time points (Fig. 2). The old animals were also no longer glucose intolerant when compared with young animals. On reviewing the insulin response at the same time it can be seen that the 15-min insulin response was significantly better in the GLP-1-treated animals compared with the controls (Fig. 3 ). Indeed, the saline-treated rats had their peak insulin level at $30 \mathrm{~min}$, while the GLP-1-treated animals peaked at $15 \mathrm{~min}$. This brisk insulin response accounted for the drop in blood glucose in the treated animals (Fig. 2). Overnight fasting levels of insulin were higher in the GLP-1-treated animals, but due

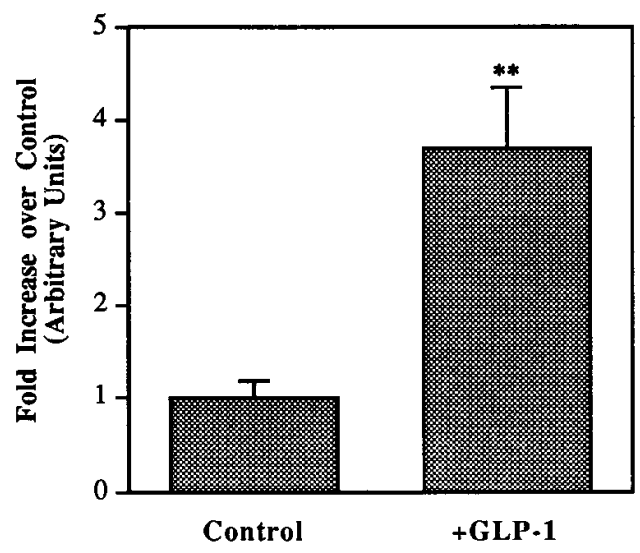

Figure 4. Fold increase in islet insulin content after $48 \mathrm{~h}$ infusion of saline (control, 7 animals) or GLP-1 (1.5 pmol $/ \mathrm{kg} \cdot \mathrm{min}, 7$ animals) in 22-mo old rats. $* * P<0.01$ by unpaired Student's $t$ test. 
to intraanimal variation, this was not statistically different from controls ( $192 \pm 47$ vs. $134 \pm 45 \mathrm{pmol} / \mathrm{liter})$.

Intraislet insulin content. There was variation in the amount of insulin between the islets from each individual pancreas as might be expected from aged animals (Fig. 4). However, there was consistently more insulin in the islets from treated animals $(P<0.01)$. Islets from controls and GLP-1-treated rats had $5.31 \pm 1.19$ vs. $19.68 \pm 3.62 \mathrm{ng}$ of insulin per $\mu \mathrm{g}$ of total pancreatic proteins, respectively.

GLP-1 plasma levels. We measured plasma GLP-1 in three animals $6 \mathrm{~h}$ after commencement of the GLP-1 infusion to insure both that steady state GLP-1 levels were reached and to

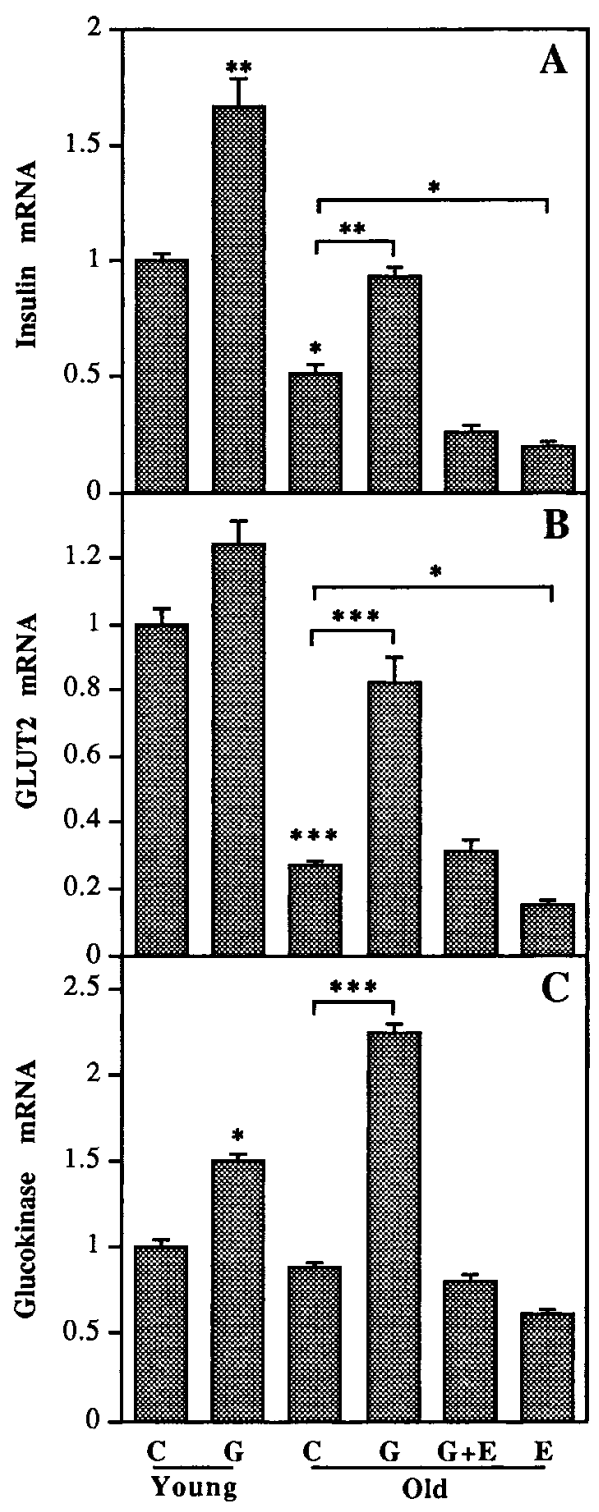

Figure 5. Effects of normal saline $(C)$, GLP-1 $(G)$, GLP-1 + exendin [9-39] $(G+E)$, and exendin [9-39] $(E)$ treatment for $48 \mathrm{~h}$ on mRNA levels of insulin, GLUT2, and glucokinase using pancreatic poly-A RNA in young and old animals. Images of cDNA hybridization were quantified using densitometry and normalized with those of poly-A. Data are shown as mean $\pm \operatorname{SEM}(n=6$ animals per group $)$ with control data assigned a value of $1 . * P<0.05, * * P<0.01$, *** $P<0.001$ by unpaired Student's $t$ test. verify that the peptide was actually being infused. Plasma GLP-1 level at $6 \mathrm{~h}$ was $106.7 \pm 17.6$ while at $48 \mathrm{~h}$ it was $125.0 \pm$ $41.4 \mathrm{pmol} /$ liter $(n=6)$. Before the commencement of the glucose tolerance testing plasma GLP-1 was below the level of detectability of the assay ( $<10$ pmol/liter). Fasting GLP-1 levels in control Wistar rats were all in the range of 10 to $20 \mathrm{pmol} / \mathrm{li}$ ter. There was no difference in the fasting levels of GLP-1 between the young and old animals. Therefore, our infusion of GLP-1 raised plasma GLP-1 levels to approximately six times the fasting levels. Fed levels in Wistar rats, as well as humans (23), are reported to approximately double after eating (16). Therefore, the plasma levels attained with the pumps were pharmacological.

Effect of GLP-1 on gene expression. We measured the abundance of insulin mRNA as well as mRNA levels of factors involved in the early steps of glucose-mediated insulin release and glucose metabolism in beta cells. Results were quantified by densitometry, normalized by using oligo dT hybridization and expressed in relative terms by assigning the young control result a value of 1. Fig. 6 shows the blots for insulin mRNA from whole pancreata in 6 young and 12 old animals and combined results from all the animals are shown in Fig. 5. Fig. 7 shows the blots of three isolated islet RNA preparations from old animals.

The levels of insulin mRNA was decreased by $\sim 50 \%$ in old vs. young animals (Fig. $5 A, P<0.05$, and Fig. 6). GLP-1 increased the insulin mRNA in both young and old animals compared to controls (Fig. $5 A, P<0.01$ and Fig. 6). Similar results can be seen in the isolated islet preparations (Fig. 7). This increase was entirely prevented when the animals were treated simultaneously with Ex, an inhibitor of GLP-1 binding to its own receptor. Of great interest is the fact that in the animals treated with Ex alone or Ex with GLP-1, the insulin mRNA levels were lower than in controls $(P<0.05)$. Insulin mRNA levels fell an average of $60 \%$ in the presence of Ex alone.

GLUT-2 mRNA levels in old animals were decreased by $70 \%$ compared with young controls and this was entirely reversed by GLP-1 treatment (Fig. $5 B, P<0.001$ ). The increase in GLUT2 mRNA levels in old animals by GLP-1 can be seen in both islet (Fig. 7) and whole pancreatic preparations (Fig. 6). In the young animals GLP-1 did not significantly influence the GLUT2 mRNA levels (Fig. 5). The levels fell by $50 \%$ in

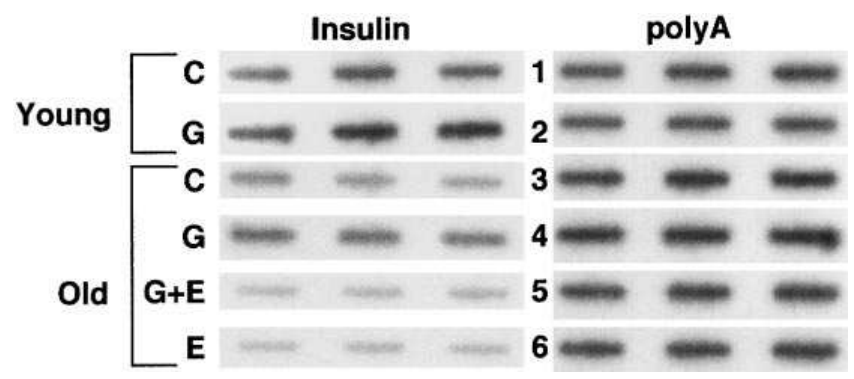

Figure 6. Slot blot analysis of insulin mRNA from total pancreatic RNA in young and old rats treated by subcutaneous infusion for $48 \mathrm{~h}$ ( $C$, control animals given normal saline; $G$, GLP-1; $G+E$, GLP-1 and exendin [9-39] given simultaneously; E, exendin [9-39] alone). Each slot represents an individual pancreas. This blot was used in the analysis in Fig. 5. 


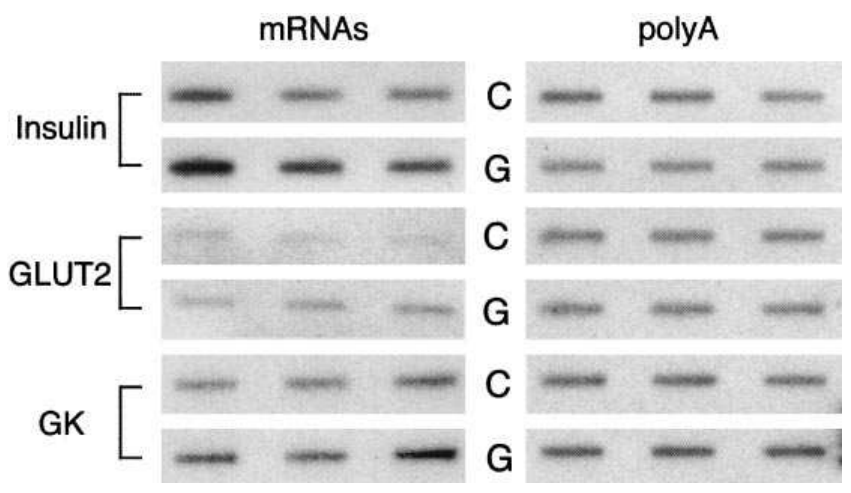

Figure 7. Slot blot analysis of insulin, GLUT2, and glucokinase (GK) mRNAs from total islet RNA of old animals. For each mRNA the top panel $(C)$ represents animals treated with normal saline while the bottom panel represents animals treated with GLP-1 $(G)$ for $48 \mathrm{~h}$. Each slot is derived from a separate islet preparation.

the presence of Ex alone (Fig. $5 B, P<0.05$ ), but not in the animals treated with Ex and GLP-1 (Fig. $5 B$ ).

There were no differences between young and old animals in glucokinase mRNA levels (Fig. $5 C$ ). GLP-1 significantly increased glucokinase levels in young (Fig. $5, P<0.05$ ) but much more so in old animals (Fig. $5 C, P<0.001$, Fig. 7). Similar results were seen in the old animals with isolated islet preparations (Fig. 7). Ex completely prevented GLP-1-induced increases in glucokinase mRNA.

For all preparations the results from the pancreata were reflected in the islets. Hexokinase I, II, and III mRNA levels were very low in the whole pancreata and islets and did not appear to be altered by GLP-1 treatment (data not shown). We also infused GLP-1 for $5 \mathrm{~d}$ into old rats $(n=6)$ and found the same results as with the 48 -h infusion (data not shown).

\section{Discussion}

Decreased insulin secretory response to glucose is the main feature of aging of the pancreatic beta cell $(12,24)$. Abnormal beta cell function in the presence or absence of insulin resistance leads to Type II diabetes (25). Aging, with its slow and progressive deterioration of beta cell functional activity, is a naturally occurring model for characterizing the biological features that lead to Type II diabetes and for designing therapeutic interventions capable of halting the natural course of the disease. Aged rats, in the food-deprived state, are equally as responsive to GLP-1 as young rats, thereby highlighting that the lesion in the beta cell of the pancreas is specific for glucose stimulation.

In this study, we demonstrate that a 48-h infusion of GLP-1 in 22-mo old Wistar rats potentiates insulin response to an IPGTT. This phenomenon is observed even after termination of the GLP-1 infusion, indicating that GLP-1 is capable of inducing long-term changes that go over and beyond modulating insulin release. We also show that the lesion in the secretory mechanism for insulin release in aging Wistar rats is reversible by GLP-1, just as it is in Type II diabetes $(7,8,18)$. The major change in the insulin-response curve was in early insulin release after the glucose load, and was induced by a shift in the maximum insulin secretion from 30 min after glucose injection, as observed in controls, to only $15 \mathrm{~min}$ in the GLP-1-treated rats.

Elahi et al. (12) showed that first phase insulin release was reduced by as much as $75 \%$ in aging Wistar rats and we previously showed that this was almost certainly due to a reduction in the number of beta cells responsive to glucose (15). What is unique in the present study is that insulin secretion remained improved even after removal of the exogenous source of GLP-1. The biological half-life of GLP-1's insulinotropic action in blood is 6-8 $\mathrm{min}$ (26) and since GLP-1 infusion had been terminated at least $2 \mathrm{~h}$ before performing the glucose tolerance testing, the continued presence of elevated GLP-1 levels, at least in the short term, was not necessary for the improvement in glucose tolerance in the aging Wistar animals. In our study in RIN 1046-38 cells (5), we showed that 24 h of treatment with GLP-1 increased glucose responsiveness even after the GLP-1 had been removed for an hour and after several washings of the cells. We propose that the infusion of GLP-1 into animals, similar to the RIN cells, had a lasting salutary effect on beta cell function, and that GLP-1 may be capable of inducing more substantial changes in the functional activity of the beta cells rather than simply increasing the secretion of preformed insulin.

In this study, we show that GLP-1 increases insulin biosynthesis and insulin mRNA levels in vivo, similar to what we have shown in insulinoma cells (5). GLP-1 would also appear to be necessary for the normal maintenance of mRNA levels of insulin in the pancreas. Not only did Ex inhibit the GLP-1 effect on insulin mRNA but it also caused a decrease in insulin mRNA in animals given Ex alone. Ex is a competitive inhibitor of GLP-1 binding to its receptor, a 10-fold higher concentration of Ex being required to inhibit GLP-1's insulinotropic effect (16), so presumably it was inhibiting the binding of endogenous GLP-1 in the animals that received Ex alone. This suggests that GLP-1 has effects on maintaining insulin mRNA levels even in the physiological range.

We found a $70 \%$ reduction in GLUT2 expression with age with no alteration in the level of expression of glucokinase. An increase in glucokinase expression has been seen previously in aged mice (27), whereas this is the first time, to our knowledge, a decreased GLUT2 expression has been reported in aged rodents. Interestingly, GLUT2 expression was not altered in the livers of the old animals (data not shown). In other animal models of experimental diabetes reduced expression of GLUT2 has been recorded and suggested to be an etiological factor in diabetes by impairing normal glucose uptake and metabolism thereby preventing normal glucose sensing (28). In the $\mathrm{db} / \mathrm{db}$ mouse, for example, there is also reduced GLUT2 expression in pancreas without alteration of its expression in the liver (29). In a transgenic mouse model expressing GLUT2 antisense RNA where GLUT2 expression was reduced by $80 \%$ the animals had significantly reduced glucose-mediated insulin release (30). This is comparable to the changes we report here in aging animals. GLP-1's beneficial effect in improving glucose-mediated insulin release in the old rats might therefore be at least partially attributed to reversing the agerelated decline in GLUT2 expression.

In conjunction with the reversal of the decline in GLUT2 expression with age by GLP-1, glucokinase expression was highly significantly increased by GLP-1 even though it was not decreased before treatment when compared with young animals. In the young animals, on the other hand, GLUT2 expres- 
sion was not significantly altered by GLP-1 treatment and glucokinase expression was not increased to the same intensity as in the older animals. Thus, it appears that GLUT2 and glucokinase expression are indeed linked, as has been suggested (31). Interestingly, and in keeping with what we found in aging, when RIN 1046-38 cells were transfected with the GLUT2 gene causing up-regulation of GLUT2 mRNA and protein, glucokinase expression was also up-regulated fourfold (32).

It has been proposed that in Type II diabetes the beta cell stores of insulin fall below a critical level, and that this causes a subsequent reduction in glucose-induced insulin responses (33). In aging rats, there is a decrease in insulin synthesis in beta cells as well as glucose-mediated insulin secretion when compared with young rats $(15,23)$. There is also a preferential release of newly formed insulin over preformed insulin in response to an acute secretory stimulus (34). Secretion of both pools of insulin is decreased in aging, with preformed insulin secretion decreased to a greater extent than newly formed insulin (34). We hypothesize that GLP-1 increased insulin biosynthesis in beta cells that could, in turn, be due to the increased GLUT2 expression and subsequent improvement in beta cell glucose sensing and glucose metabolism. This resulted in increasing the pool of newly formed insulin such that a larger amount of insulin became available for acute release during the IPGTT. We have also shown that GLP-1 is capable of inducing beta cells into a secretory mode (35) and more beta cells would therefore probably be responding to the glucose stimulus in the GLP-1-treated animals. The increase in newly formed insulin, coupled to a probable increase in the number of responsive beta cells in conjunction with increased GLUT2 expression explains why insulin release was so substantially improved in our old Wistar rats in the early part of the IPGTT. As GLP-1 increased total intraislet insulin content to such a large extent, it also raises the possibility that GLP-1 not only increased insulin within existing cells but it may be recruiting new beta cells that would have added to the existing pool of cells available for insulin synthesis.

GLUT2 gene expression can be transactivated by a transcription factor, variously known as IPF-1, STF-1, IDX-1, and PDX-1 via an identified GLUT2TAAT motif (36). This same transcription factor is also known to promote insulin and somatostatin gene expression, thus suggesting a closely correlated regulation of these genes. We show this same closely correlated regulation by GLP-1 of these genes in our aged animals. It is interesting that a decline in IDX-1 promoter activity with age in rodents has been suggested already (37). We intend to investigate if this holds true with age in our animals and if GLP-1 is capable of increasing IDX-1 promoter activity.

As our data show, GLP-1 is capable of increasing intraislet insulin content, and when given continuously, rather than just by bolus, may also induce changes beneficial to beta cell function, over and beyond its effects on simply insulin secretion. It remains to be seen if the same phenomena can occur in humans. If so, this would make it an ideal and unique candidate for the long-term treatment of Type II diabetes.

\section{Acknowledgments}

We would like to thank the Director of the NIA, Dr. Richard Hodes, who encouraged us to do this study. This study would not be possible without the help of Dr. Joel Habener at the Laboratory of Molecular Endocrinology, Massachusetts General Hospital, Howard Hughes
Medical Institute, Boston. We had several discussions with him, and his laboratory assayed GLP-1 in the rat plasma. Last, but not least, Denis Muller (NIA) helped us with the statistics.

\section{References}

1. Thorens, B., and G. Waeber. 1993. Glucagon-like peptide-1 and the control of insulin secretion in the normal state and in NIDDM. Diabetes. 42:12191225 .

2. Orskov, C. 1992. Glucagon-like peptide-1, a new hormone of the enteroinsular axis. Diabetologia. 35:701-711.

3. Drucker, C.J., J. Philippe, S. Mosjov, W.L. Chick, and J.F. Habener. 1987. Glucagon-like peptide 1 stimulates insulin gene expression and increases cyclic AMP in a rat islet cell line. Proc. Natl. Acad. Sci. USA. 84:3434-3438.

4. Fehmann, H.C., and J.F. Habener. 1992. Insulinotropic hormone glucagon-like peptide-1 (7-37) stimulation of proinsulin gene expression and proinsulin biosynthesis in insulinoma $\beta$ TC-1 cells. Endocrinology. 130:159-166.

5. Wang, Y., J.M. Egan, M. Raygada, O. Nadiv, J. Roth, and C. MontroseRafizadeh. 1995. Glucagon-like peptide-1 affects gene transcription and messenger ribonucleic acid stability of components of the insulin secretory system in RIN 1046-38 cells. Endocrinology. 136:4910-4917.

6. Wang, Y., C. Montrose-Rafizadeh, L. Adams, M. Raygada, O. Nadiv, and J.M. Egan. 1996. GIP regulates glucose transporters, hexokinases, and glucose-induced insulin secretion in RIN 1046-38 cells. Mol. Cell. Endocrinol. 116: 81-87.

7. Nauck, M.A, M.M. Heimesaat, C. Orskov, J.J. Holst, R. Ebert, and W. Creutzfeldt. 1993. Preserved incretin activity of glucagon-like peptide 1 (7-36) amide but not of synthetic human gastric inhibitory polypeptide in patients with Type-2 diabetes mellitus. J. Clin. Invest. 91:301-307.

8. Nauck, M.A., N. Kleine, C. Orskov, J.J. Holst, B. Willms, and W Creutzfeldt. 1993. Normalization of fasting hyperglycemia by exogenous glucagon-like peptide 1 (7-36) amide in Type 2 (non-insulin-dependent) diabetic patients. Diabetologia. 36:741-744.

9. Holz $4^{\text {th }}$, G.G., W.M. Kuhtreiber, and J.F. Habener. 1993. Pancreatic beta-cells are rendered glucose-competent by the insulinotropic hormone glucagon-like peptide-1 (7-37). Nature (Lond.). 361:362-365.

10. Widmann, C., W. Dolci, and B. Thorens. 1996. Desensitization and phosphorylation of the glucagon-like peptide-1 (GLP-1) receptor by GLP-1 and 4-phorbol 12-myristate 13-acetate. Mol. Endocrinol. 10:62-75.

11. Nadiv, O., O. Cohen, and Y. Zick. 1992. Defects in insulin's signal transduction in old rat livers. Endocrinology. 130:1515-1524.

12. Elahi, D., D.C. Muller, D.K. Andersen J.D. Tobin, and R.A. Andres. 1985. The effect of age and glucose concentration on insulin secretion by the isolated perfused pancreas. Endocrinology. 116:11-16. 180.

13. Porte, D., Jr. 1991. $\beta$-cells in Type II diabetes mellitus. Diabetes. 40:166-

14. Leahy, J.L. 1990. Natural history of B-cell dysfunction in NIDDM. Diabetes Care. 13:992-1010.

15. Perfetti, R., C. Montrose-Rafizadeh, A.S. Liotta, and J.M. Egan. 1995. Age-dependent reduction in insulin secretion and insulin mRNA in isolated islets from rats. Am. J. Physiol. 269:E983-E990.

16. Wang, Z., R.M. Wang, A.A. Owji, D.M. Smith, M.A. Ghatei, and S.R. Bloom. 1995. Glucagon-like peptide-1 is a physiological incretin in rat. J. Clin. Invest. 95:417-421.

17. Egan, J.M., C.M. Asplin, M.A. Drumheller, J.R. Kerrigan, J. Scott, P.M Martha, Jr., and W.S. Evans. 1991. Glucose stimulated insulin release by individual beta cells: potentiation by glyburide. J. Exp. Med. Biol. 196:203-210.

18. Nathan, D.M., E. Schreiber, H. Fogel S. Mosjov, and J.F. Habener 1992. Insulinotropic action of glucagonlike peptide-1-(7-37) in diabetic and nondiabetic subjects. Diabetes Care. 15:270-276.

19. Glisin, V., R. Crkvenjakov, and C. Byrus. 1974. Ribonucleic acid isolated by cesium chloride centrifugation. Biochemistry. 13:2633-2637.

20. Chigwin, J.M., A.E. Przybyla, R.J. MacDonald, and W.J. Rutter. 1979. Isolation of biologically active ribonucleic acid from sources enriched in ribonuclease. Biochemistry. 18:5294-5299.

21. Matschinsky, F. 1990. Glucokinase as glucose sensor and metabolic signal generator in pancreatic $\beta$-cells. Diabetes. 39:647-652.

22. Mueckler, M. 1990. Family of glucose-transporter genes. Implications for glucose homeostasis and diabetes. Diabetes. 39:6-11.

23. Gutniak, M., C. Orskov, J.J. Holst, B. Ahren, and S. Efendic. 1992. Antidiabetogenic effect of glucagon-like peptide-1 (7-36) amide in normal subjects and patients with diabetes mellitus. N. Engl. J. Med. 326:1316-1322.

24. Wang, S.Y., P.A. Halban, and J.W. Rowe. 1988. Effects of aging on insulin synthesis and secretion. Differential effects on proinsulin messenger messenger mRNA levels, proinsulin biosynthesis, and secretion of newly made and preformed insulin in the rat. J. Clin. Invest. 81:176-184.

25. Arver, P., T. Pollare, and H. Lilhell. 1991. Different aetiologies of type 2 (non-insulin-dependent) diabetes mellitus in obese and non-obese subjects. $\mathrm{Di}$ abetologia. 34:483-487.

26. Elahi, D., M. McAloon-Dyke, N.K. Fukagawa, G.S. Meneilly, A.L. Sclater, K.L. Minaker, J.F. Habener, and D.K. Andersen. 1994. The insulino- 
tropic actions of glucose-dependent insulinotropic polypeptide (GIP) and glucagon-like peptide-1 (7-37) in normal and diabetic subjects. Regul. Peptides. 51: 63-74.

27. Perfetti, R., Y. Wang, S.R. Shuldiner, and J.M. Egan. 1996. Investigation of age-related changes in mouse endocrine pancreas. J. Gerontol. 51:B331B336.

28. Unger, R.H. 1990. Diabetic hyperglycemia: link to impaired glucose transport in pancreatic $\beta$ cells. Science (Wash. DC). 251:1200-1205.

29. Thorens, B., Y.-J. Wu, J.L. Leahy, and G.C. Weir. 1992. The loss of GLUT2 expression by glucose-unresponsive $\beta$ cells of $\mathrm{db} / \mathrm{db}$ mice is reversible and is induced by the diabetic environment. J. Clin. Invest. 90:77-85.

30. Valera, A., G. Solanes, J. Fernandez-Alverez, A. Pujol, J. Asins, R. Gomis, and F. Bosch. 1994. Expression of GLUT-2 antisense RNA in $\beta$ cells of transgenic mice leads to diabetes. J. Biol. Chem. 269:28543-28546.

31. Pilkis, S.J., I.T. Weber, R.W. Harrison, and G.I. Bell. 1994. Glucokinase: structure analysis of a protein involved in susceptibility to diabetes. J. Biol. Chem. 269:21925-21928.

32. Ferber, S., H. BeltrandelRio, and J.H. Johnson. 1994. GLUT-2 gene transfer into insulinoma cells confers both low and high affinity glucose-stimu- lated insulin release. J. Biol. Chem. 269:11523-11529.

33. Hosokawa, Y.A., H. Hosokawa, C. Chen, and J.L. Leahy. 1996. Mechanism of impaired glucose-potentiated insulin secretion in diabetic $90 \%$ pancreatectomy rats. Study using glucagonlike peptide-1 (7-37). J. Clin. Invest. 97:180-186.

34. Wang, S.Y., and J.W. Rowe. 1988. Age-related impairment in the short term regulation of insulin biosynthesis by glucose in rat pancreatic islets. Endocrinology. 123:1008-1013.

35. Montrose-Rafizadeh. C., J.M. Egan, and J. Roth. 1994. Incretin hormones regulate glucose-dependent insulin secretion in RIN 1046-38 cells: mechanism of action. Endocrinology. 135:589-594.

36. Waeber, G., N. Thompson, P. Nicod, and C. Bonny. 1996. Transcriptional activation of the GLUT2 gene by the IPF-1/STF-1/IDX-1 homeobox domain. Mol. Endocrinol. 10:1327-1334.

37. Stoffers, D., R.S. Heller, C.P. Miller, and J.F. Habener. 1996. Expression of homeodomain factor IDX-1 in pancreas and duodenum: discordance among expression of an IDX- $1 \beta$-galactosidase transcriptional reporter, IDX-1 mRNA and protein. Tenth International Congress of Endocrinology: P2-35 (Abstr.). 